\title{
Pemahaman Muslim Berlangganan Restoran Halal: Peran Logo Halal dan Sikap Konsumen di Kota Bogor
}

\author{
Understanding Muslims Subscribe to Halal Restaurants: The Role of the \\ Halal Logo and Consumer Attitudes in the City of Bogor
}

\author{
Andika Nuraga Budiman, Intan Tri Annisa \\ Management Study Program, Faculty of Economics and Business, YARSI University, Jakarta \\ Jalan Letjen. Suprapto, Cempaka Putih, Jakarta 10510 \\ Telepon (021) 4206674, 4206675, 4206676 \\ E-mail: andika.nuraga@yarsi.ac.id
}

KEYWORDS halal logo, MUI certification, restaurant and consumer's perception

ABSTRACT The purpose of this study is to investigate the perception of Muslim costumers who always subscribing Halal restaurant without any doubt whenever they find Halal logo in restaurant or without it. This research is already finished with supported of SPSS ver.23. 200 respondents were giving the contribution to make this research. The result shows that despite all the hypothesis testing were investigate significantly, the mediation of consumer's attitude was significantly mediate them to subscribe Halal restaurant. Which is the Muslim of Bogor were keep the Islam rule as an obligation to always consume permissible food and beverage in guarantee Halal in restaurant.

\section{PENDAHULUAN}

Makanan adalah sumber daya fundamental dalam kehidupan seharihari, mengandung nutrisi, seperti protein, karbohidrat, lemak, mineral dan vitamin, untuk menyediakan energi untuk hidup dan berkembang. Industri makanan saat ini menawarkan berbagai warna dengan makanan berkualitas yang telah diuur oleh produk-produk standar dari industri makanan. Pada dasarnya, semua produk makanan diizinkan, kecuali secara eksplisit dilarang dalam Al-Quran (Bab II, Ayat 168) seperti alkohol, daging babi, darah, daging dari bangkai, dan daging hewan yang belum disembelih menurut aturan Islam (Bonne \& Verbeke, 2008). Pengalaman Indonesia telah ditunjukkan dalam bentuk kendala pada perubahan konsumsi pangan bagi konsumen, perubahan konsumsi pangan sehingga perubahan gaya hidup konsumen dari waktu ke waktu untuk mengubah makanan yang dikonsumsi akan lebih berbeda (Maziz \& Raymond, 2017). Sebagai negara berkembang, orang sekarang menghadapi tantangan menjaga keamanan, keterjangkauan, kenyamanan, dan makanan lezat di lingkungan yang berubah dari waktu ke waktu (Dyck et al., 2011).

Industri makanan dan minuman di Indonesia telah berkembang dalam 
beberapa tahun terakhir, dibantu oleh kelas menengah dan keadaan tingkat daya beli mereka. Pemerintah telah menargetkan peningkatan industri untuk terus tumbuh sebesar $8,15 \%$ pada 2013, sementara Asosiasi Produsen Makanan dan Minuman Indonesia (GAPMMI) memperkirakan bahwa penjualan makanan dan minuman di tingkat nasional secara keseluruhan naik $10 \%$ menjadi US \$77,39 miliar pada tahun 2013, Indonesia adalah pasar makanan impor utama. Sebuah negara kelas menengah dengan skala besar dan berkembang, meningkatkan kesadaran pola hidup sehat di sektor ritel modern telah memberikan kontribusi untuk peningkatan permintaan untuk produkproduk pangan impor. Tren konsumen di Indonesia yang mereka sukai adalah merek dan produk internasional dari luar negeri, terutama di usia anak dan remaja.

Berdasarkan latar belakang di atas, penulis mengidentifikasi sebuah masalah, yaitu, Seorang Muslim telah menyadari pentingnya berlangganan restoran halal, tetapi mereka terikat oleh kecenderungan lain untuk mengkonsumsi makanan dan minuman di restoran tanpa ragu-ragu bahkan restoran tersebut tidak memiliki logo halal. Berlangganan restoran halal telah menjadi gaya hidup, tetapi salah satu atribut restoran, logo halal adalah alasan untuk berlangganan.

Populasi umat Islam di Indonesia telah mencapai $89 \%$ dari total penduduk negara ini (BPS, Jakarta 2010). Jumlah populasi ini membawa dampak peluang bagi pembisnis yang berbasis Halal. Berdasarkan database Negara Ekonomi Islam Global dari yang telah dinyatakan dalam laporan Reuters (2016), bahwa Indonesia telah menduduki tingkat pertama sebagai lokasi konsumen
Muslim yang mengkonsumsi makanan Halal. Muslim di Indonesia menjunjung tinggi nilai Syariah dalam setiap aspek kehidupannya, salah satu indikatornya adalah mereka pertimbangkan konsumsi produk Halal sebagai prinsip Islam.

Sebuah perkermbangan ini merupakan peluang bagi pembisnis dan produsen agar memenuhi standar Halal. Disamping itu kemajuan ilmu pengetahuan dan teknologi menjadi sebuah aspek kehidupan. Penelitian Hayati \& Khairul (2009) telah menyatakan bahwa adanya hal-hal yang belum diakui oleh masyarakat telah menjadi sebuah kenyataan. Khairul menyatakan salah satu perkembangan yang perlu dipertimbangkan adalah pada bisnis makanan, obat-obatan, dan kosmetik. Beberapa tahun lalu ketiga sector itu tidak begitu terlihat sebagai masalah oleh Muslim.amun Muslim sekarang terlihat ragu-ragu menggunakan produk tersebut. Fenomena ini dapat menimbulkan beberapa keraguan; apakah produk tersebut boleh dikonsumsi atau tidak. Keragu-raguan seperti itu tidak terlalu banyak, terutama bagi umat Islam karena masalah halal dan kesucian harus sangat dipertimbangkan pada hal-hal yang mereka konsumsi dan gunakan untuk kepentingan agama mereka.

Permasalahan Halal yang terjadi di atas adalah peristiwa yang sudah biasa dialami oleh masyarakat Bogor. Dengan adanya fenomena yang telah disebutkan diatas, penelitian ini tertarik untuk investigasi persepsi Muslim Bogor yang mana telah mencoba beberapa kali atau berlangganan restoran Halal. Penelitian ini menginvesitigasi pengaruh Halal Logo terhadap berlangganan restoran Halal bagi Muslim di Bogor. 


\section{METODOLOGI}

Penelitian ini berasaskan pada TRA (Theory Reasoned Action) dari Fishbein and Ajzen (1975) sebagai landasan teori yang menginvestigasi persepsi konsumen berdasarakan pengaruh Halal Logo terhadap sikap konsumen, dan juga menginvestigasi kedua hubungan itu terhdapat berlangganan restoran Halal (Direct Relationship and Indirect Relationship). TRA telah diciptakan berdasarkan sebuah alasan yang aktual dari konsumen setelah melakukan sebuah aktifitas yang telah dipengaruhi oleh variabel pengaruh (Independent Variable). Kerangka ini menjadikan sikap konsumen sebagai mediator dari Variabel $\mathrm{X}$ yang akan mempengaruhi Variabel Y. Artinya, penelitian ini percaya bahwa adanya stimulan dari sikap konsumen untuk berlangganan restoran Halal yang dibandingkan dengan tanpa adanya pengaruh mediasi dari sikap konsumen.

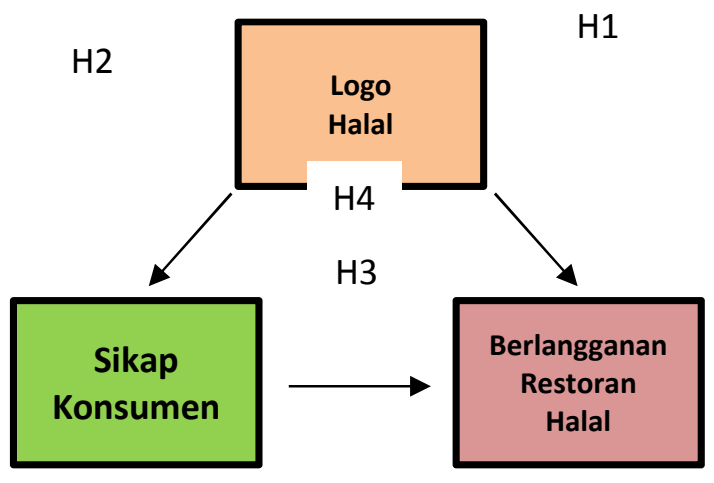

Gambar 1. Kerangka Teoritis

Berdasarkan Gambar 1 di atas, dapat diketahui ada 3 Hipotesis yang dilakukan dalam penelitian ini. Hubungan langsung dan tidak langsung menjadi hasil untuk penelitian ini. Hipotesis 1 (H1) adalah adanya hubungan yang signifikan antara Halal logo terhdap Berlangganan Restoran Halal. Hipotesis 2 (H2) adalah adanya hubungan yang signifikan antara Halal logo terhadap sikap konsumen. Hipotesis 3 (H3) adalah adanya hubungan yang signifikan antara sikap konsumen terhadap berlangganan restoran Halal. Dan terakhir, Hipotesis 4 (H4) adalah adanya mediasi sikap konsumen bagi Halal logo dan berlangganan restoran Halal.

Lokasi penelitian ini didasarkan pada Masalah Halal yang terjadi di Indonesia, Bogor. Responden yang menjadi sampel dalam penelitian ini adalah Orang-orang Muslim yang telah berani mencoba berkunjung pada restoran yang memiliki Halal Logo dengan frekuensi sebanyak minimal 3 kali return. Hal ini menjadikan konsumen ini menjadi seorang pelanggan yang loyal dan juga setidaknya mereka memiliki kemampuan menjawab dengan yakin apabila dimintai isi kuesioner penelitian ini. 
ISI

1. Analisis Deskriptif

Pertanyaan-pertanyaan kuesioner telah di adaptasikan sebagaimana pertanyaan yang memfokuskan pada semua variabel-variabel dalam penelitian ini. Dimulai dari instrumen persepesi kualitas pelayanan yang telah diadaptasikan dari penelitian Dali, et al. (2007). Selanjutnya instrumen pertanyaan sikap konsumen direferensikan dari penelitian Firman (2010), dan instrumen pertanyaan berlangganan restoran Halal direferensikan dari penelitian Prasad (2012). Berikut hasil analisis deskriptif penelitian.
Dari hasil Tabel 1 diatas menunjukkan hasil dari analis deskriptif dari semua variabel (Peresepsi Kualitas Pelayanan, Sikap Konsumen, dan Berlangganan Restoran Halal). Hasil Deskriptif untuk persepsi kualitas pelayanan mayoritas mengarah pada jawaban yang positif (setuju) terhadap kualitas pelayanan yang telah diberikan oleh pihak restoran. Sikap Konsumen telah menunjukkan efek sikap yang positif terhadap restoran Halal dan hasil dari berlangganan restoran Halal mendapatkan jawaban yang positif dari responden penelitian ini.

Tabel 1. Daftar Pertanyaan Kuesioner Penelitian

\begin{tabular}{|c|c|c|c|}
\hline Nama Variabel & Petanyaan (Disesuaikan) & MEAN & Std.Deviation \\
\hline Logo Halal & $\begin{array}{l}\text { - Saya akan senangtiasa mencari Logo Halal di Restoran } \\
\text { Halal sebelum saya masuk dan duduk di dalamnya. } \\
\text { - Semua makanan dan produk untuk konsumen yang } \\
\text { lain dari Restoran Halal perlu mendapatkan } \\
\text { pengesahan resmi dari MUI. } \\
\text { - Metode Restoran Halal juga penting dalam } \\
\text { menentukan status halal } \\
\text { - Logo Halal dapat meyakinkan Muslim untuk } \\
\text { mengunjungi di Restoran non-Muslim }\end{array}$ & $\begin{array}{r}3.3 \\
2\end{array}$ & 0.714 \\
\hline Sikap Konsumen & $\begin{array}{l}\text { - Restoran Halal adalah sesuatu yang bagus } \\
\text { - Restoran Halal itu dapat dipercaya. } \\
\text { - Restoran Halal itu amat bermanfaat bagi saya. } \\
\text { - Restoran Halal itu mempunyai informasi tentang } \\
\text { Halal-nya. } \\
\text { - Secara keseluruhannya saya suka Restoran Hala } \\
\text { - Secara umumnya, saya menerima Restoran Halal }\end{array}$ & $\begin{array}{r}3.4 \\
4\end{array}$ & 0.553 \\
\hline $\begin{array}{l}\text { Berlangganan } \\
\text { Restoran } \\
\text { Halal }\end{array}$ & $\begin{array}{l}\text { - Secara keseluruhannya, saya fikir berlangganan } \\
\text { Restoran Halal adalah hal yang benar untuk dilakukan. } \\
\text { - Saya berhasrat untuk berlangganan ke restoran Halal di } \\
\text { masa yang akan datang } \\
\text { - Saya berhasrat untuk berlangganan restoran Halal } \\
\text { secara rutin } \\
\text { - Saya akan menyarankan restoran Halal ini dengan } \\
\text { kawan saya dan saudara saya. }\end{array}$ & 3.46 & 1.73 \\
\hline
\end{tabular}


Dari hasil Tabel 1 diatas menunjukkan hasil dari analis deskriptif dari semua variabel (Peresepsi Kualitas Pelayanan, Sikap Konsumen, dan Berlangganan Restoran Halal). Hasil Deskriptif untuk persepsi kualitas pelayanan mayoritas mengarah pada jawaban yang positif (setuju) terhadap kualitas pelayanan yang telah diberikan oleh pihak restoran. Sikap Konsumen telah menunjukkan efek sikap yang positif terhadap restoran Halal dan hasil dari berlangganan restoran Halal mendapatkan jawaban yang positif dari responden penelitian ini.

\section{Analisis Reliatbilitas}

Uji Reliabilitas telah dilakukan dalam penelitian ini dengan hasil yang signifikan. penelitian terdahulu Nunnaly \& Bernstein (1994) yang menjadikan penelitian mereka sebagai azaz untuk tolak ukur batas minimal uji validitas dalam penelitian ini. Mereka menyatakan bahwa point minimal untuk uji reliabilitas sudah signifikan dengan Cronbach Alpha melebihi 0.50, akan lebih baik lagi jika lebih dari 0.70. Oleh karena itu Cronbach Alpha dalam penelitian ini telah menggunakan cut point 0.70 dengan hasil pada tabel dibawah ini.

Tabel 2. Uji Reliabilitas

\begin{tabular}{lr}
\hline \multicolumn{1}{c}{ Variabel } & Cronbach Alpha \\
\hline $\begin{array}{l}\text { Logo Halal } \\
\text { Sikap }\end{array}$ & 0.754 \\
Konsumen & \\
Berlangganan & 0.894 \\
Restoran Halal & \\
\hline
\end{tabular}

\section{Analisis Regresi Linier}

Pengujian semua hipotesis telah dilakukan dengan analisis linier regresi dengan uji $\mathrm{T}$ parsial yang telah menguji setiap hipotesis antara independent variabel dengan dependent variabel dengan menggunakan $\mathrm{T}$ tabel $=1.980$. Adanya hubungan yang signifikan antara Halal logo terhadap Berlangganan Restoran Halal $(\mathrm{p}=0.00<0,05)$. Selain itu, adanya hubungan yang signifikan antara Halal logo terhadap Sikap Konsumen $(\mathrm{p}=0,00<0,05)$. Uji T parsial dengan mencari hubungan yang signifikan antara Logo Halal dengan berlanggganan restoran Halal telah memiliki hubungan yang signifikan positif.Adanya hubungan yang signifikan antara Sikap Konsumen terhdap Berlangganan Restoran ( $\mathrm{p}=0,00>0,05)$.

\section{Analisis Mediasi}

Pengujian ini untuk mengivestigasikan peran mediasi sikap konsumen Muslim terhadap berlangganan resotoran Halal. Baron dan Kenny (1986) mengusulkan pendekatan empat langkah di mana beberapa analisis regresi dilakukan dan signifikansi koefisien diperiksa pada setiap langkah namun langkah keempat hanyalah berlaku jika memiliki lebih dari satu variabel X. Pada penelitian ini hanya membandingan Hubungan langsung dan Hubungan tidak langsung (Direct relationship and Indirect Relationship). Hubungan Langsung adalah Logo Halal Berlangganan Restoran Halal. Sedangkan hubungan tidak langsung adalah Logo Halal - Sikap Konsumen - Berlangganan Restoran Halal.

Pada Gambar 2. mediasi sikap konsumen terlihat sangat signifikan dengan hubungan yang tidak langsung. Sikap konsumen dapat menstimulasi tingkat signifikasi terhadap berlangganan restoran Halal dengan melalui hubungan tidak langsung (Logo Halal - Sikap Konsumen - Berlangganan Restoran Halal). Dengan adanya hubungan tidak langsung dengan hasil $0.642(\mathrm{p}=000)$ 


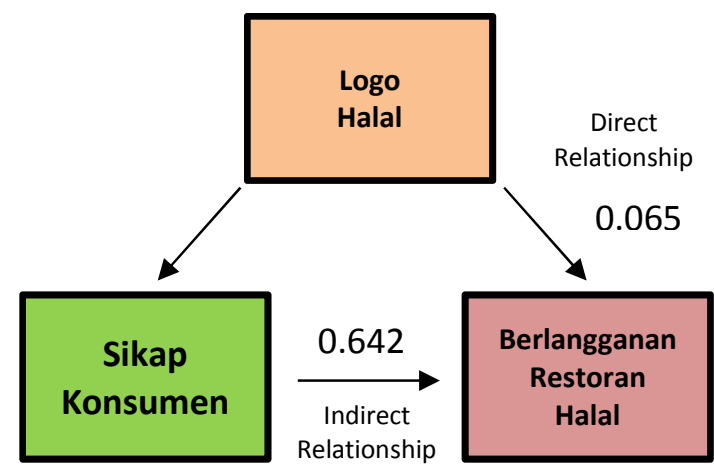

Gambar 2. Analsis Mediasi Kota Bogor

maka dapat dikatakan sorang Muslim di Bogor selalu berlangganan Restoran Halal dengan adanya Logo Halal yang dilandaskan dengan sikap mereka sebagai Muslim untuk berlangganan sedangkan untuk hubungan langsung tidak begitu besar nilai signifikasinya dengan hasil dari analisis sebesar $0.65(\mathrm{p}=0.274)$ artinya seorang Muslim Bogor tidak dapat berlangganan restoran tanpa adanya sebuah sikap sebagai mediator. Dengan demikian, hasil-hasil dari semua analisis pengujian hipotesis, telah di uji dengan sedemikian rupa sehingga mendapat hasil yang signifikan.

Data dari studi sebelumnya Ibrahim dan Vignali (2005) menyelidiki sikap konsumen terhadap niat sikap berlangganan terhadap restoran cepat saji, dengan demikian hasil penelitian menunjukkan bahwa hasil analisis regresi dalam model klasik menunjukkan bahwa sikap tersebut mempengaruhi niat berlangganan konsumen terhadap restoran cepat saji internasional. Juga, Smith (2015) bertujuan untuk menyelidiki dampak kemasan ramah lingkungan pada sikap konsumen dan niat perlindungan terhadap merek-merek ritel pakaian. Hasil penelitian menunjukkan bahwa sikap konsumen memiliki hubungan yang signifikan dengan niat perlindungan terhadap paket ramah lingkungan di toko ritel. Studi lain yang dilakukan Yoo \& Naeyon (2014) menemukan bahwa sikap konsumen terhadap pengecer mode cepat sebagian memediasi pengaruh hubungan dari nilai emosional pada niat berlangganan. Dari hasil di atas, sikap konsumen memiliki pengaruh yang signifikan terhadap niat berlangganan, selanjutnya sikap konsumen adalah bagian dari variabel dalam studi ini. Ini menarik untuk menyelidiki mediasi sikap konsumen terhadap restoran halal yang dilindungi. Studi sebelumnya oleh Tawfik. et. al. (2008) menyelidiki niat konsumen Malaysia untuk berlangganan restoran dengan hukum syariah. Hasil penelitian menunjukkan bahwa ada hubungan antara sikap, Norma Subjektif, dan Kontrol Sikap Persepsi terhadap niat berlangganan Rumah Makan Halal. Juga, Tawfik dan Aminul (2011) menyelidiki faktor-faktor yang mempengaruhi Muslim Malaysia untuk berlangganan restoran halal. Hasil penelitian menunjukkan bahwa ada hubungan antara sikap. Norma Subjektif dan Kontrol Sikap Persepsi terhadap niat untuk berlangganan Restoran HALALHalal. Ditemukan bahwa sikap, norma subjektif dan kontrol sikap persepsi memiliki hubungan yang signifikan dan positif dengan niat Sikap untuk berlangganan restoran Halal. 
Peneliti lain, Soesilowati et al. (2010) melaporkan bahwa sertifikat Majelis Ulama Indonesia (MUI) di Indonesia tidak begitu penting bagi persepsi pemilik restoran. Dia juga menemukan bahwa label halal pada kemasan juga tidak begitu penting untuk melayani pelanggan. Logo Halal dari MUI jauh lebih dipercaya untuk melayani pelanggan karena label Halal dari MUI lebih dipercaya daripada label Halal dari departemen lain agama Indonesia bahkan logo Halal dari departemen agama Indonesia jauh lebih bermaksud untuk peduli toko dan restoran. Sistem Manajemen Lingkungan (EMS) pengusaha di Indonesia dirasakan bahwa sertifikasi Halal dengan tujuan untuk mempromosikan pelanggan kepuasan, kepercayaan dan terpercaya tapi masalah memperoleh Status Halal Status dari MUI adalah proses yang panjang dan mahal. Karena ini, hanya sejumlah usaha kecil dan menengah yang mendaftarkan produk mereka.

\section{PENUTUP}

Responden penelitian memiliki pengaruh yang signifikan terhadap berlangganan restoran Halal. Responden memiliki persepsi yang baik terhadap restoran Halal. Logo Halal dapat memberikan pengaruh pada sikap konsumen Muslim Bogor . Muslim yang selalu berlangganan restoran Halal, selalu dimediasikan oleh sikap mereka sebagai Muslim yang taat dengan aturan Islam yang berkewajiban untuk selalu mengkonsumsi makanan dan minuman dari restoran Halal.

\section{DAFTAR PUSTAKA}

Baron, R.M., David, A.K..1986. The Moderator-Mediator Variable Distinction in Social Psychological Research: Conceptual, Strategic, and Statistical Considerations. Journal of Personality and Social Psychology. 51 (6):1173-82.

Bonne, K., \& Verbeke, W. 2008. Religious values informing halal meat production and the control and delivery of halal credence quality. Agriculture and Human Values. 25(1), 35-47.

BPS, Jakarta. 2010. Jakarta in figures 2010. BPS, Jakarta 2010. Publication Number: 31550.1002. BPS Catalogue: 1102001.31.

Dali, N., Sulaiman, S., Samad, A. 2007. Halal Products From The Consumers Perception. An online survey:1-64

Dyck, J., Woolverton, A. E., Fahwani, Y.,R. 2012). Indonesia's Modern Food Retail Sector: Interaction with Changing Food Consumption and Trade Patterns. United States Department of Agriculture. Issue, 9. Pp. 37.

Firman, J. 2010. Consumer Attitudes Toward Mobile Advertising. Department of Marketing and management. Aalti University. pp. 111 .

Hayati, A.T., Khairul, A.M. 2009. An overview of Malaysian food industry: The opportunity and qualityaspects. Pak. J. Nutr., 8: 507-517

Ibrahim, Y., \& Vignali, C. 2005. Predicting Consumer Patronage Behaviour in the Egyptian Fast Food Business. Innovative Marketing. 1(2), 60-76 
Mazis B., M., Raymond A.M. 1997. Consumer perception of health claims in advertisements and on food labels. The Journal of Consumer Affairs. 10-26.

Nunnally, J., Bernstein, L. 1994. Psychometric theory. New York: McGraw-Hill Higher, INC; 1994.

Prasad, R.,K.,Y. 2012. A Study of Consumers, Retail Format Choice \& Patronage Behaviour in Food \& Grocery Retailing (With Special Reference to Neighbourhood Kirana Stores and Supermarkets in Twin Cities of Hyderabad \& Secunderabad). 294-313.

Reuters, T. 2016. Annual Report 2016. Published on March 9, 2017.

Smith, M.M.. 2015. Impact of environmentally friendly packaging on consumers' attitudes and patronage intentions toward apparel retail brands. General Human Environmental Sciences Undergraduate Honors Theses. Paper 13.

Soesilowati, E.S., Jusmaliani, U.K., Yani, M., Diah, S. 2010. Business Opportunities for Halal Products in the Global Market: Muslim
Consumer Behaviour and Halal Food Consumption, J. Indones. Soc. Sci. Hum. 3:151-160

Tawfik M.S. 2008. Intention to Patronage Halal Restaurants among Malaysian Muslims an Issue of Halal Perception. Universiti Sains Malaysia. April 2008

Tawfik, S.M. \& Aminul, Md., I. 2011. Factor Influencing Malaysian Muslim to Patronage Halal Restaurants-Ambience as a Mediator. Business Review. 6(2).

Fishbein, M., Ajzen, I. 1975. Belief, Attitude, Intention and Behavior: An introduction to theory and research. Reading, MA: Addison Wesley.

Wilson, J.A.J. 2012. The new wave of transformational Islamic marketing: Reflections and definitions. Journal of Islamic Marketing, 3(1): 5-11.

Yoo \& Naeyon. 2014. Predicting consumer attitude and patronage intention toward fast fashion retailers: an illustration from U.S. college students. Retrieved from the University of Minnesota Digital Conservancyhttp://hdl.handle.net/ $\underline{11299 / 169381}$. 